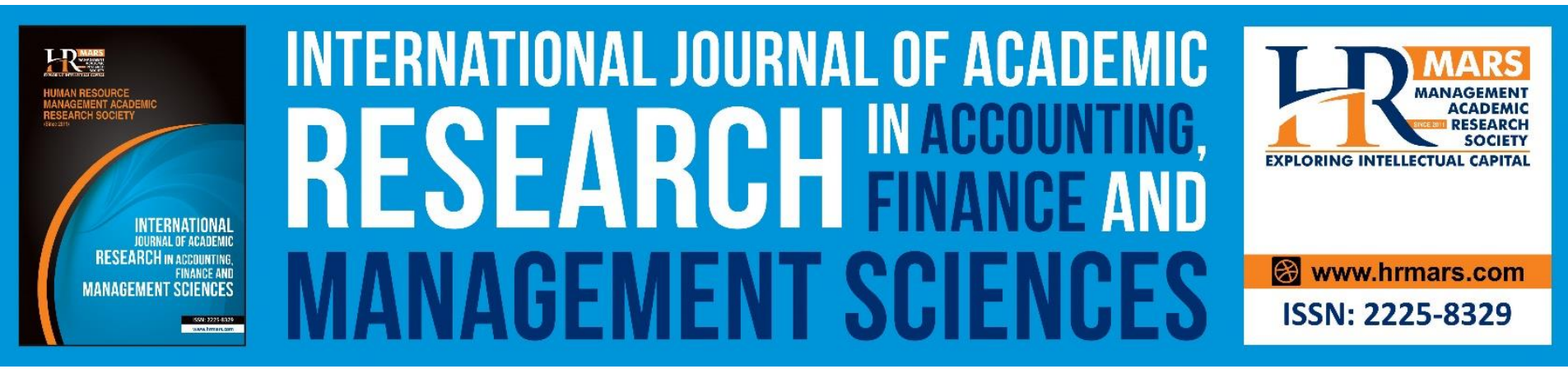

\title{
Impact of Accounting Function Outsourcing on SMEs Financial Performance and Efficiency: Evidences from some selected Manufacturing Subsectors in Nigeria
}

Danjuma Mohammed, Rukaiyatu Adamu

To Link this Article: http://dx.doi.org/10.6007/IJARAFMS/v10-i3/7921

DOI:10.6007/IJARAFMS /v10-i3/7921

Received: 17 July 2020, Revised: 20 August 2020, Accepted: 05 September 2020

Published Online: 29 September 2020

In-Text Citation: (Mohammed, \& Adamu, 2020)

To Cite this Article: Mohammed, D., \& Adamu, R. (2020). Impact of Accounting Function Outsourcing on SMEs Financial Performance and Efficiency: Evidences from some selected Manufacturing Subsectors in Nigeria. International Journal of Academic Research in Accounting, Finance and Management Sciences. 10(3), 204225.

Copyright: (c) 2020 The Author(s)

Published by Human Resource Management Academic Research Society (www.hrmars.com)

This article is published under the Creative Commons Attribution (CC BY 4.0) license. Anyone may reproduce, distribute, translate and create derivative works of this article (for both commercial and non-commercial purposes), subject to full attribution to the original publication and authors. The full terms of this license may be seen at: http://creativecommons.org/licences/by/4.0/legalcode

Vol. 10, No. 3, 2020, Pg. 204 - 225

Full Terms \& Conditions of access and use can be found at http://hrmars.com/index.php/pages/detail/publication-ethics 


\title{
Impact of Accounting Function Outsourcing on SMEs Financial Performance and Efficiency: Evidences from some selected Manufacturing Subsectors in Nigeria.
}

\author{
Danjuma Mohammed (PhD), Rukaiyatu Adamu \\ Department of Accounting, Adamawa State University Mubi, Nigeria. \\ Email: mohammed509@adsu.edu.ng, 84mammyru@gmail.com
}

\begin{abstract}
This study examined the impact of accounting function outsourcing on SMEs financial performance and efficiency in manufacturing sector. The main focus is to determine whether accounting functions drive financial performance and efficiency in Nigeria's SMEs. To achieve this objective both primary and secondary data were extracted and analyzed to generate the study findings. The study used survey research design with a sampled population of six hundred SMEs across the study area. The study revealed that accounting function outsourcing has significant relationship with SME efficiency thus enhance financial performance. The study therefore, recommends the practice of accounting functions outsourcing to the owner/managers of SMEs for sustainable business growth.

Keywords: Efficiency, Financial Performance, Outsourcing, Manufacturing, Nigeria.
\end{abstract}

\section{Introduction}

Many business failures are attributed to the fact that accounting processes, concepts and conventions are circumvented, neglected or to some extend being ignored completely. Accounting service is one critical function of every institution be it governmental or non-governmental, public or private and whether large or small. Small Manufacturing Enterprises just like sole proprietorship or ordinary partnership business are not compelled by law to publish their accounts for external consumption. But they maintain records be it financial, cost or tax records by employees of such business. However, some of these in-house staff may lack adequate knowledge and training in keeping both cost, financial and tax records appropriately. This is prevalent because of lack of expertise since application of accounting functions is not only accounting conventions or tax regulations is involved but also expertise in handling rules of a given business environment (Everaert, Sarens and Rommel, 2010). Therefore, it is a tradition at the end of each financial year; every business entity prepares the financial position of its business.

However not all the SMEs can prepare the financial statements of its business adequately and accurately in-house. Inadequate handling of fundamental accounting functions by the stewards of small manufacturing enterprises due to lack of expertise now calls for outsourcing. The small 
manufacturing enterprises referred to in this study are those which are not quoted in the Nigerian stock exchange. Therefore, the SMEs had to resort to outsourcing accounting services for record strengthening, regulation conformity, business core competence, cost reduction and competitive advantage. Outsourcing is the shifting of business risk or function either in wholly or partly from a main company to a third party (Butler, 1991). Outsourcing is widely embraced in Nigeria as of now especially in manufacturing, telecommunication and other service industries (Mohammed, 2014) Outsourcing of non-core functions especially accounting services to outside supplier for timely, accurate, effective and adequate accounting information for managerial decision making process as well as external users' requirement. Yurong (2004) outsourcing is a contractual agreement between vendor and a client enterprise in which the vendor assumes responsibility as an agent to undertake some or more of the business functions of this enterprise for the enterprise. It is quite alarming that outsourcing is gaining grounds in Nigeria particularly in SME sector where a reasonable number of them outsourced their support functions such back office services, financial statement preparation, tax related services among others (Mohammed, 2014). This drive calls the need for SME's owners/managers to become complimentary with outsourcing vendors in consolidating on their core competencies by the former and the latter concentrates on the support services to achieve enhanced performance. With this alliance SME's in Nigeria will be more focused on their business strategies, customer satisfaction and yield performance. Outsourcing accounting functions obviously have significant effects on the performance of SME's in emerging economies (Kamyabi \& Devi, 2011) and it is applicable to Nigeria whose features are similar.

The world now has become a global village, boundaries and distances has lost their significance value in competitive business environment as information technology has bridged the gap of frontiers and physical distance between the parties to a transaction. Today information can reach any geographical location of the transacting party fast and easily regardless of distance or boundary barrier. Global competition has become a bit easier for new entrants in the competitive business environment as information technology allows customers to make a choice anywhere they to engage a supplier services. In this sense the SME's operating within Nigeria has an opportunity to outsource its accounting services from a vendor in India, China, America, Europe or anywhere in the world. SME's therefore the opportunity to access specialist with quality and best practice to manage its accounting functions with greater speed and accuracy at the same time at lesser cost. Accounting services outsourcing allows SME's to focus and concentrate on its core competencies and enjoy competitive advantage. SME's and outsourcing vendors become complimentary agents in discharging business activities (Corbett, 2004) while the SME's perform their core competencies the outsourcing undertakes the accounting services operations.

Outsourcing has the inherent to advance the performance and reduce the cost in areas that brings no or less competitive advantage. Outsourcing non-core competencies from a better vendor gives firm an edge over its competitors and standard of performance of SME's now becomes higher (Hammel \& Prahalad, 1990). Tom Peters "Do what you do best and outsource the rest" the bottom line here is that firms should focus on their core competencies and outsource non-core operations.

According to Baiye (2012) Outsourcing involves making available of human resources and assets involved to the outsourcing business associates. This implies that accounting services outsourcing involves scarifying tangible and intangible assets necessary for the processing and interpreting resourceful accounting information to a specialist by the SME's to achieve competitive advantage the 
acceptability of outsourcing as a desired tool for achieving business strategy in which a company buys a product or service rather than make it is becoming alarming (Desai, 2012). For SME's to survive market competition the need to buy their accounting services which in most cases is not their core competencies rather than to produce it themselves will achieve effective business strategy. Dana (2012) outsourcing is an additional team support provided external vendors on contractual relationship to undertake tasks managed previously by in- house staff for which the vendors are experienced specialist, experts and have better competencies. Accounting services such as preparation of financial statements, accounts payable, accounts receivables, taxation, returns alike are periodic and needs expertise in other to maintain consistent interval reporting fast, adequate and accurate. The speed, adequacy and accuracy is dependent on the expertise of the staff involved in its preparation, in-house staff of SME's can concentrate on their other administrative responsibilities whereas the firm decides to outsource those activities. Those accounting services are very critical to the survival of the SME's in the business environment despite it being a support service. Outsourcing and sub-contracting concepts in a business were sometimes mixed up by laymen but clearly contrasted as, outsourcing to involve substantial restructuring of a particular business operation which include transferring of staff from a client enterprise to a specialist outsourcing vendor whereas sub-contracting is engaging contractors for particular business task(s) which results in a long-term relationships with such organizations to complement the company's abilities in performing such activity (Gandja \& Estay, 2012). Outsourcing concept is not this new to business environment but to Nigeria; SME's practice outsourcing phenomenon and particular accounting services outsourcing to strengthened their records for tax purposes, bank loanable facilities, credit worthiness and attracting potential investors among others. The strength and weakness of companies lies in their corporate performance analysis; therefore, SME's are not excluded. Therefore, this study examined the impact of outsourcing accounting services on the financial performance and efficiency of SMEs in Nigeria.

\section{SME's Efficiency and Transaction Cost Theory}

Transaction Cost Economics (TCE) explains which structural form is responsible for or should be used in organizing a given transaction for example a firm whose core competence is consisting three stages of production, $\mathrm{S}_{1}, \mathrm{~S}_{2}$ and $\mathrm{S}_{3}$ as illustrated by Williamson (1985) in Efficient Boundary. This is the core competence of the firm and it undertakes to perform it by in-house. Production input raw materials, $R$ is decided by the firm not at all to perform it in-house as well as distribution of finished products $D$. the production stages $S_{x}$ is only assumed to be performed internally by the firm to suit this illustration not necessarily in reality. The rationale here always is that decisions about activity performed by a firm will be justified by the reasoning of TCE.

The various stages of the production process $S_{x}$ each uses a component $C_{x}$ which has to be produced it is left for the firm to decide whether to produce it in-house $\left(C_{x}-1\right)$ or to outsource it from a competent outside supplier $\left(C_{x}-O\right)$. It applies to the distribution process $D$, as well in the sense $D-I$ if the Firm uses its personal distribution channel (in-house) or D-O if the distribution is outsourced from an expert vendor. The various alternative transactions 1-4 i.e $C_{x}-S_{x}(x=1,2,3)$ and $S_{3}-D$ is a function of organizing in-house or to outsource from an outside supplier which is explained by the bolded boundary line. This therefore shows that $C_{2}$ is done in-house, $D$ is also kept in-house while component $C_{1}$ and $C_{3}$ were outsourced. It also shows that transactions $C_{1}-S_{1}$ and $C_{3}-S_{3}$ are outsourced outside whereas $C_{2}-S_{2}$ and $S_{3}-D-I$ are organized within the firm (in-house). 


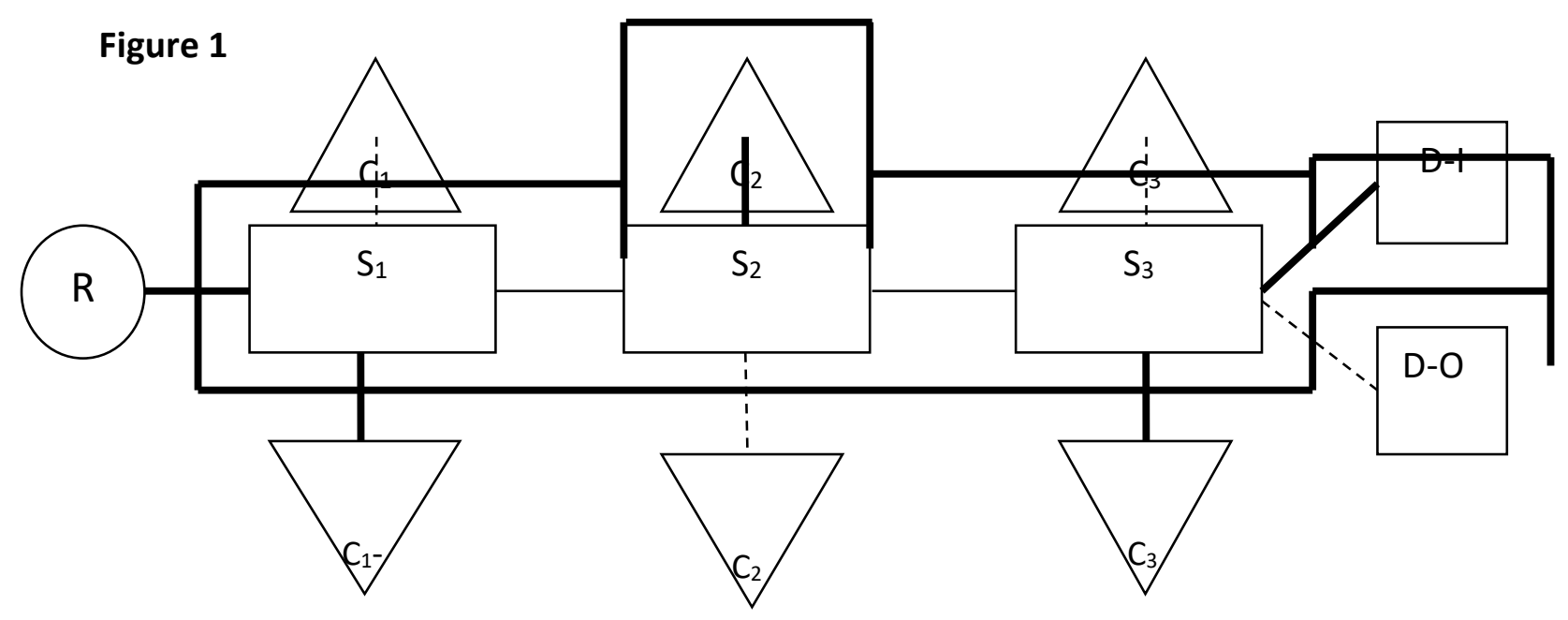

Efficient Boundary, Adapted from Williamson (1985)

As TCE originated in 1937 his work "The Nature of the Firm" Coase discover the reason why firm exist in a specialized exchange economy. TCE therefore is all encompassing of the organizational forms onto transactions. If the need for coordination is tackled by price mechanism, then why organization is exist (Coase 1937) argue that transactions should unit of analysis whereas firms and markets on the hand are alternative organisational forms used for organizing transactions both. Market organizations rely upon price mechanism which has costs of using it and firm exist because such costs (Coase 1937). The requirement for transacting on markets is that prices had to be established and contract designed. The autonomy of the participants would bring about the conflicting interest and results to cost of negotiating and designing the contract i.e. transaction cost. Though some of the costs is subject to be avoided through performing in-house.

\section{Performance of SME's in a Competitive Business Environment}

Performance is a measure of how well a mechanism or process achieve its purpose. It's also to know how well the organization is managed and the value the organization delivers for customers and other stakeholders (Hafiz \& Andersen, 2014).

Performance measurement in the manufacturing sector of Nigerian economy may be viewed as in Suraju and Hamed (2013) the assessment of five key dimensions such as; quality of product, speed of delivery, reliability of delivery, cost and flexibility. If these factors are put into consideration when measuring performance, it will better reflect the interest of the stakeholders of the enterprise.

Performance therefore in this study is defined as using the economic resources effectively and efficiently to attain the objectives of the Nigerian SME's both externally and internally. This definition achieves the fundamental dimensions of performance measurement which is effectiveness and efficiency (Suraju \& Hamed, 2013). Effectiveness means achieving the stakeholders' requirements while efficiency is the use of economic resources economically to meet stakeholders' satisfaction. SME's attain superiority relative performance only when they achieve their set objectives with greater efficiency and effectiveness. 


\section{Methodology}

This study is exploratory, descriptive quantitative and survey of 975 SME's in Nigeria. The approach which was applied ensured increasing reliability, validity of evaluation and strong based findings. Survey method was adopted for this study through administration of questionnaire. The questionnaire contained both structured and unstructured questions. Data for the study was obtained from both primary and secondary sources. The primary source of data was obtained from structured questionnaire and informal personal interviews. The secondary sources of the data were collected via various annual reports of Central Bank of Nigeria (CBN), National Bureau of Statistics (NBS), and Manufacturers Association of Nigeria (MAN). The population of the study will be 975 SMEs across the six (6) North East States (Adamawa, Bauchi, Borno, Gombe, Taraba and Yobe) in Nigeria. The survey data was collected with the aid of research assistants in some of the sampled states. The sample of this study consists of six hundred (600) SMEs from Other Manufacturing; Food, Beverages and Tobacco; and Textile, Apparel and Footwear selected by simple random sampling method across the sample area. Multiple regression model was used in analyzing the data collected from these various sources, descriptive statistics through mean and standard deviation of variables, simple percentages, frequencies and charts were used for inferential purposes where need be. The statistical inferences were used to achieve the objectives of the study through providing solution to the research questions posed by the study.

\section{Model Specification}

Specification of the latent variables was through structural equation modeling. Construct loading for one of the indicator of every variable was fixed to 1.0 in the model to produce a scale for the latent variable. However, the final measurement model includes eight (6) latent variables designated by individual items relating to each scale. These variables are as follows: turnover (Sales Value), Productivity (output produced), Profitability (input output difference in naira value), Operating Cost, independence (patent/copy right) and customer satisfaction (market share) were analyzed.

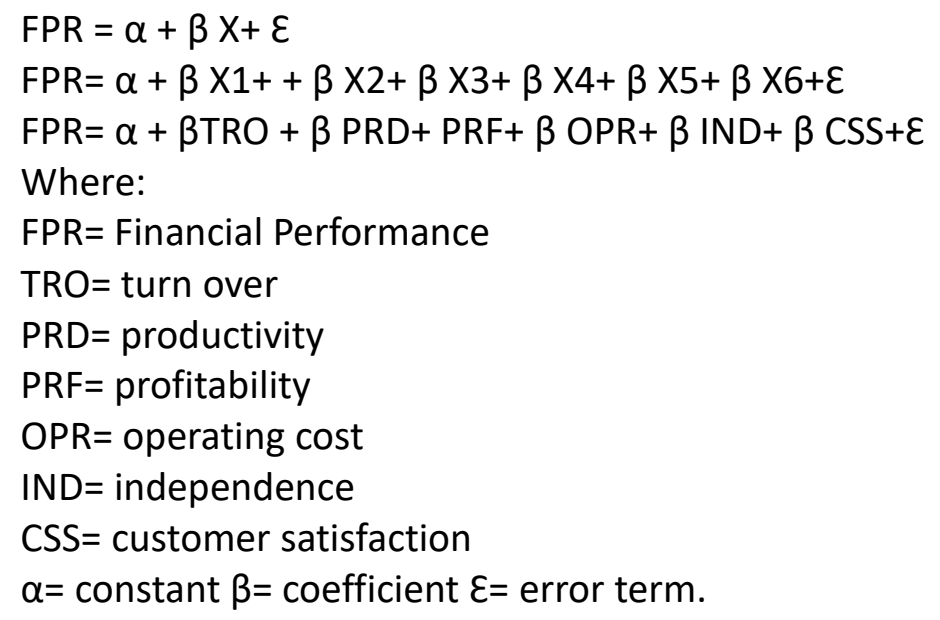

\section{Results and Discussion}

\section{Demographic Profile of Respondents and Firm Characteristics Analysis}

Firm size in this study was operationalized to be measured in terms of the initial startup capital and the number of employees of the organization. 
INTERNATIONAL JOURNAL OF ACADEMIC RESEARCH IN ACCOUNTING, FINANCE AND MANAGEMENT SCIENCES

Vol. 10, No. 3, 2020, E-ISSN: 2225-8329 @ 2020 HRMARS

Table 1 the gender of respondents

\begin{tabular}{|c|c|c|c|c|}
\hline Gender & Frequency & Percentage & $\begin{array}{l}\text { Cumulative } \\
\text { frequency }\end{array}$ & $\begin{array}{l}\text { Cumulative } \\
\text { percentage }\end{array}$ \\
\hline Male & 559 & 93.09 & 559 & 93.09 \\
\hline Female & 41 & 6.91 & 600 & 100 \\
\hline
\end{tabular}

Source: Researcher's survey extracts 2020.

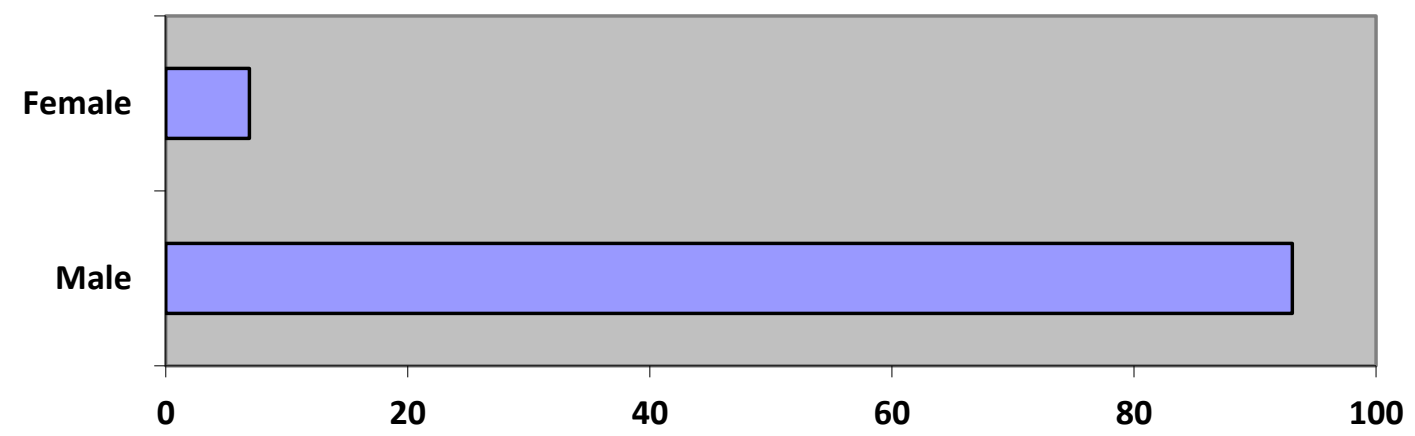

Figure 1 : Gender distribution of respondents in percentage

\section{$\square$ Gender}

\section{Gender Representation of the Respondents}

From table 1 as represented in figure 1, it reveals that majority of the owners/managers of the SME's involved in the study were male with 93.09 percent. Very few owners/managers are female representing only 6.91 percent. The SME's shows ownership by gender status is dominated by male gender with a very wide difference of 86.18 percent. This uncovers that the gender participation in ownership status is quite unequal, female entrepreneurs lag behind and needs improvement.

Table 2 age of owners/ managers

\begin{tabular}{|l|l|l|l|l|}
\hline Age & Frequency & Percentage & $\begin{array}{l}\text { Cumulative } \\
\text { frequency }\end{array}$ & \multicolumn{1}{|c|}{$\begin{array}{l}\text { Cumulative } \\
\text { percentage }\end{array}$} \\
\hline Below 20 & 1 & 0.2 & - & - \\
\hline $20-25$ & 8 & 1.4 & 9 & 1.6 \\
\hline $26-35$ & 72 & 12 & 81 & 13.6 \\
\hline $36-45$ & 240 & 40 & 321 & 53.6 \\
\hline $46-50$ & 172 & 28.6 & 493 & 82.2 \\
\hline Above 50 & 107 & 17.8 & 600 & 100 \\
\hline
\end{tabular}

Source: Researcher's survey extracts 2020 


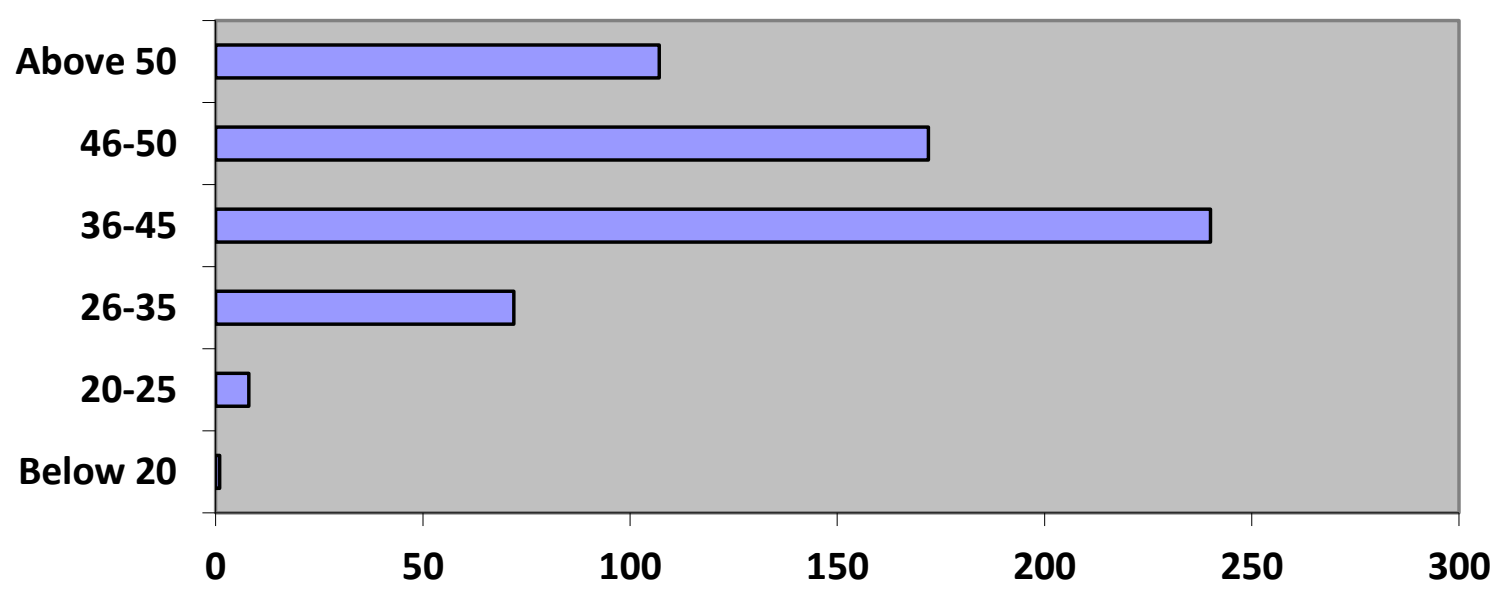

Figure 2 Age distribution of respondents by frequency.

\section{$\square$ Age}

The majority age of owners/managers lies in their youthful age where 26-35 constitute 12 percent, 46-50 has 28.6 percent and 36-45 represents 40 percent ranking first, second and third respectively. The age range below 20 years has the lowest percentage of 0.2 percent. This distribution shows that those involved in managing the affairs SME's involved in this study are at their productive labor age. The ownership by age status constitute more of matured minds than un-matured.

Table 3 highest qualification attained by owners/managers

\begin{tabular}{|l|l|l|l|l|}
\hline $\begin{array}{l}\text { Form of } \\
\text { qualification }\end{array}$ & Frequency & \multicolumn{1}{l}{ Percentage } & $\begin{array}{l}\text { Cumulative } \\
\text { frequency }\end{array}$ & $\begin{array}{l}\text { Cumulative } \\
\text { percentage }\end{array}$ \\
\hline $\begin{array}{l}\text { No education } \\
\text { Non formal } \\
\text { education }\end{array}$ & 18 & 3 & - & - \\
\hline Primary school & 72 & 10 & 78 & 13 \\
\hline $\begin{array}{l}\text { Secondary } \\
\text { school }\end{array}$ & 132 & 12 & 150 & 25 \\
\hline Technical school & 24 & 22 & 282 & 47 \\
\hline NCE/ND & 66 & 4 & 306 & 51 \\
\hline B.Sc/HND & 168 & 11 & 372 & 62 \\
\hline Postgraduate & 60 & 28 & 540 & 90 \\
\hline SOurce: Researcher S & 10 & 600 & 100 \\
\hline
\end{tabular}

Source: Researcher's survey extracts 2020. 
INTERNATIONAL JOURNAL OF ACADEMIC RESEARCH IN ACCOUNTING, FINANCE AND MANAGEMENT SCIENCES

Vol. 10 , No. 3, 2020, E-ISSN: 2225-8329 @ 2020 HRMARS

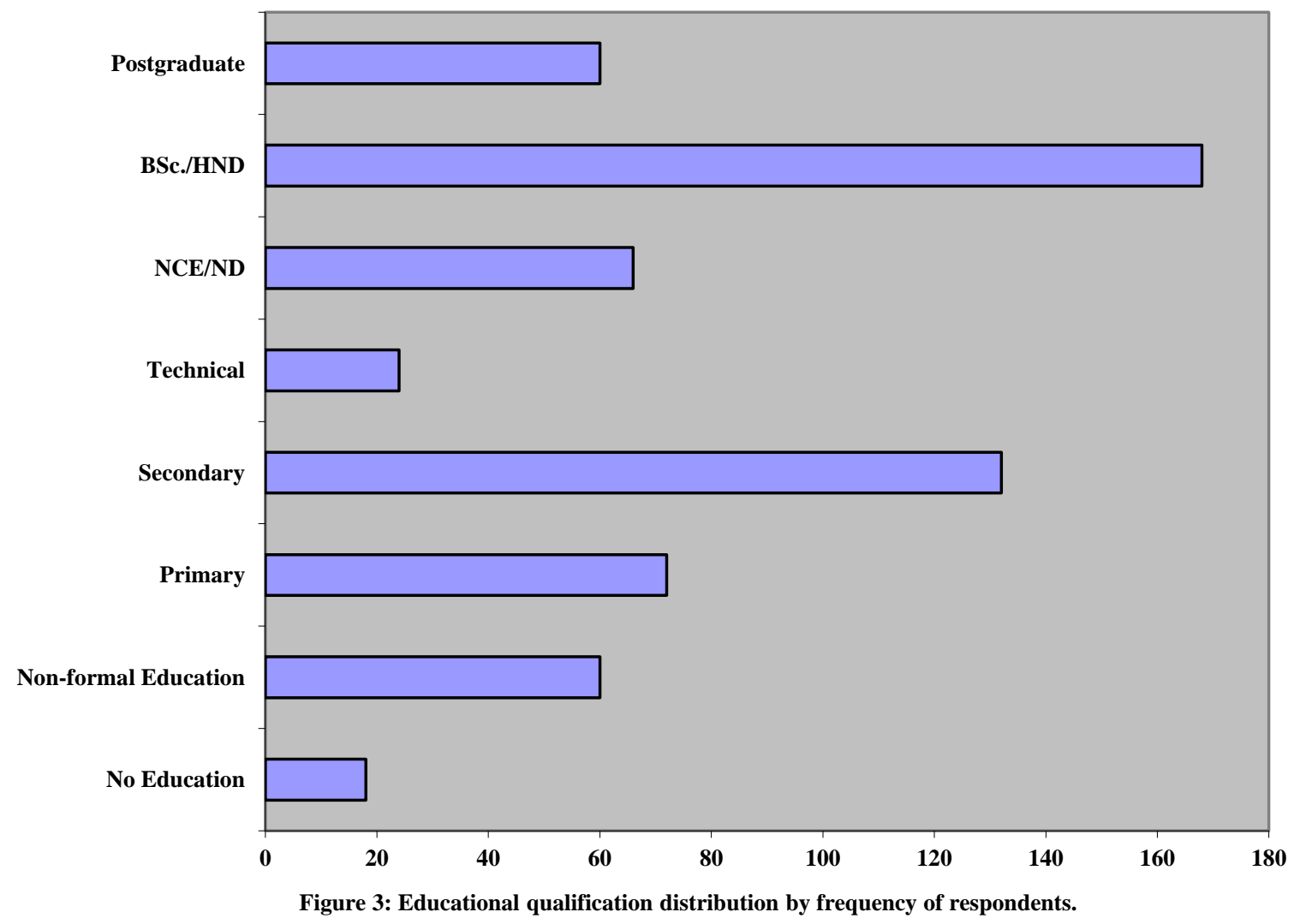

口Qualification

The distribution of owners/managers educational qualification as represented above reveals that B.Sc/HND certificate holders has the highest percentage of 28 percent followed by Secondary School Certificate holders representing 22 percent and thirdly by Primary School Leavers of 12 percent. Amongst the various qualifications, No Education has the lowest percentage of 3 percent. This distribution therefore shows that the educational qualification of the respondents is fairly good in operating a small and medium sized enterprises since less ignorant people are involved in managing the business.

Table 4: Firm size determination using initial start-up capital (NGN Million)

\begin{tabular}{|l|l|l|}
\hline Total capital & Number of enterprises & Percentage \\
\hline $10-19$ & 482 & 80.3 \\
\hline $20-29$ & 48 & 8.0 \\
\hline $30-39$ & 25 & 4.2 \\
\hline $40-49$ & 6 & 1.0 \\
\hline $50-59$ & 15 & 2.5 \\
\hline Above 60 & 24 & 4.0 \\
\hline Total & 600 & 100.0 \\
\hline
\end{tabular}

Source: Researcher's survey extracts 2020. 


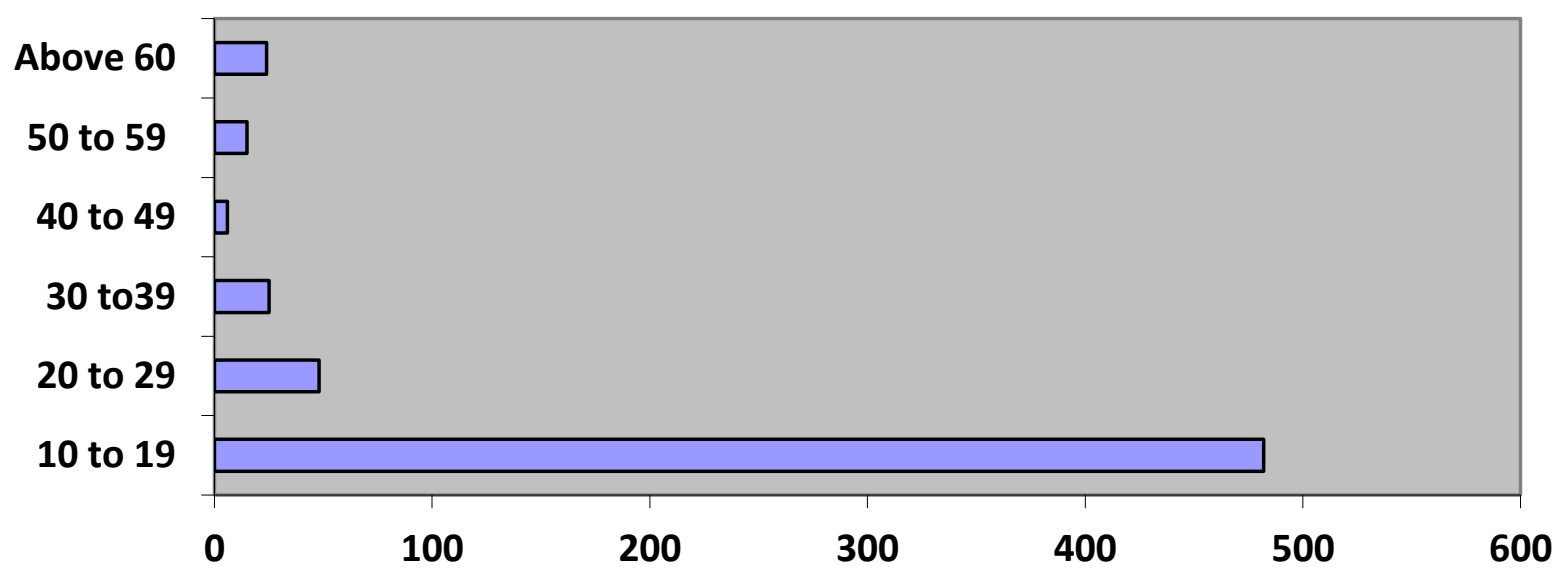

Figure 4 Startup capital of firms in NGN millions by frequency of respondents.

\section{$\square$ capital}

The above table reveals that majority of the firms are characterized as small enterprises with capital excluding land and building from 10-19 million naira as 80.30 percent followed by firm with initial startup capital of 20-29 million naira as 8.0 percent, after that by 30-39-million-naira capital constituting 4.20 percentage. The least among the firm initial startup capital which observed only 1.0 percentage is the firm categorized in 40-49-million-naira total capital.

Table 5 the number of employees

\begin{tabular}{|l|l|l|l|l|}
\hline Employees & Frequency & Percentage & $\begin{array}{l}\text { Cumulative } \\
\text { frequency }\end{array}$ & $\begin{array}{l}\text { Cumulative } \\
\text { percentage }\end{array}$ \\
\hline $10-19$ & 200 & 33 & - & - \\
\hline $20-29$ & 132 & 22 & 332 & 55 \\
\hline $30-39$ & 120 & 20 & 452 & 75 \\
\hline $40-49$ & 75 & 13 & 527 & 88 \\
\hline $50-199$ & 73 & 12 & 600 & 100 \\
\hline
\end{tabular}

Source: Researcher's survey extracts 2020. 


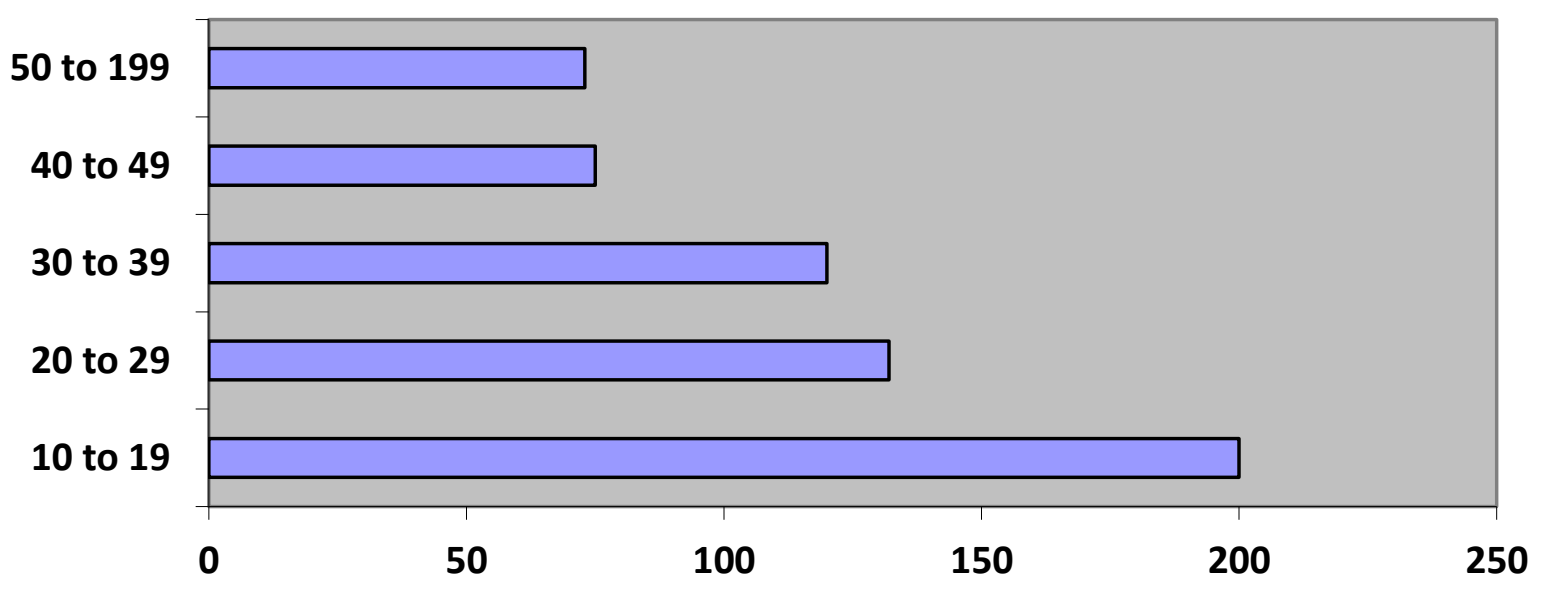

Figure 5: number of employees by frequency of respondents.

\section{口Employees}

The number of employees 10-19 represents 33 percent which is the highest followed by $20-29$ at 22 percentage points and 30-39 constituting 20 percent. The category of firms with employees of 50-199 which is by SMEDAN definition is medium sized enterprise is having the least percentage at 12 points. This means that the constituent characteristics of the firms involved in the study with respect to number of employees is mostly small sized enterprises with fewer medium sized.

Table 6 Firm age in business operation

\begin{tabular}{|l|l|l|l|l|}
\hline Age & Frequency & Percentage & $\begin{array}{l}\text { Cumulative } \\
\text { frequency }\end{array}$ & $\begin{array}{l}\text { Cumulative } \\
\text { percentage }\end{array}$ \\
\hline $\mathbf{0 - 4}$ & 225 & 38 & - & - \\
\hline $\mathbf{5}-10$ & 167 & 28 & 392 & 96 \\
\hline $11-15$ & 158 & 26 & 550 & 98 \\
\hline $16-20$ & 38 & 6 & 588 & 100 \\
\hline Above 20 & 12 & 2 & 600 & \\
\hline
\end{tabular}

Source: Researcher's survey extracts 2020. 


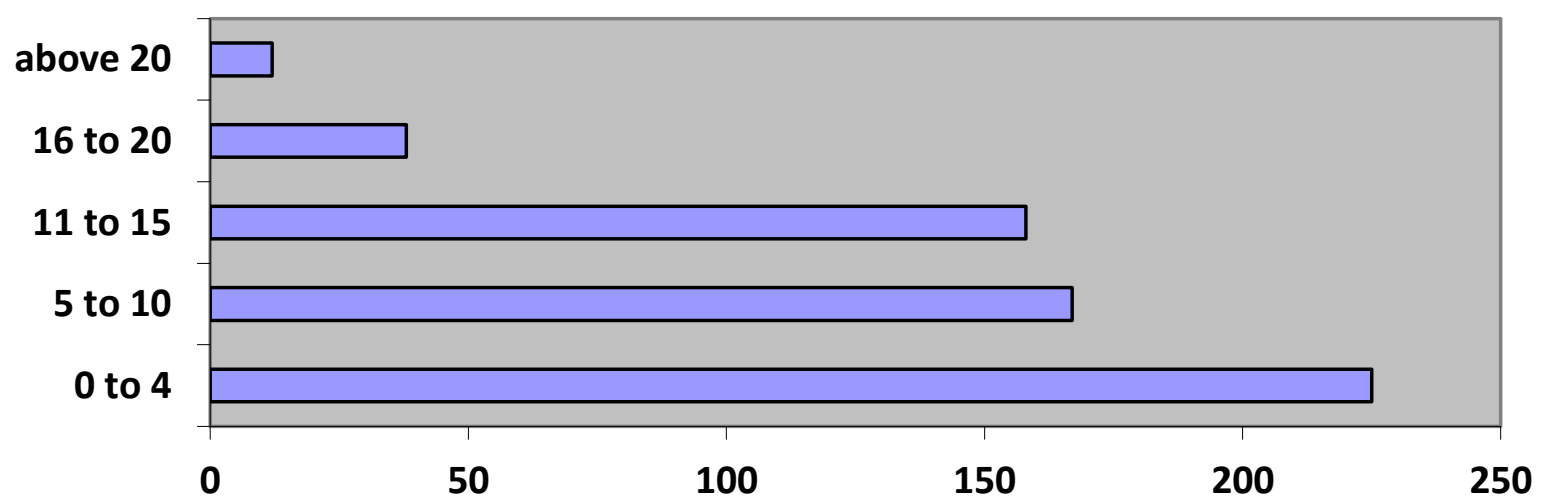

Figure 6: Firm age by frequency of the respondents.

\section{$\square$ Firm Age}

Firm age in business operation is determined by the date of incorporation i.e. business registration. The business operating within first four years of registration constitute the majority with 38 percentage points, followed by the 5-10 years in operations at 28 percent and the SME's operating for the past 15 years constitute 26 percent of the sample size. The SME's in operating in the business environment above twenty years is the least with only 20 firms involved and 2 percent as their magnitude.

Table 7 firm category of business operation

\begin{tabular}{|c|c|c|c|c|}
\hline Category & Frequency & Percentage & $\begin{array}{l}\text { Cumulative } \\
\text { frequency }\end{array}$ & $\begin{array}{l}\text { Cumulative } \\
\text { percentage }\end{array}$ \\
\hline Domestic based & 594 & 99 & & - \\
\hline Foreign based & & & & \\
\hline Domestic/Foreign & 6 & 1 & 600 & 100 \\
\hline
\end{tabular}

Source: Researcher's survey extracts 2020.

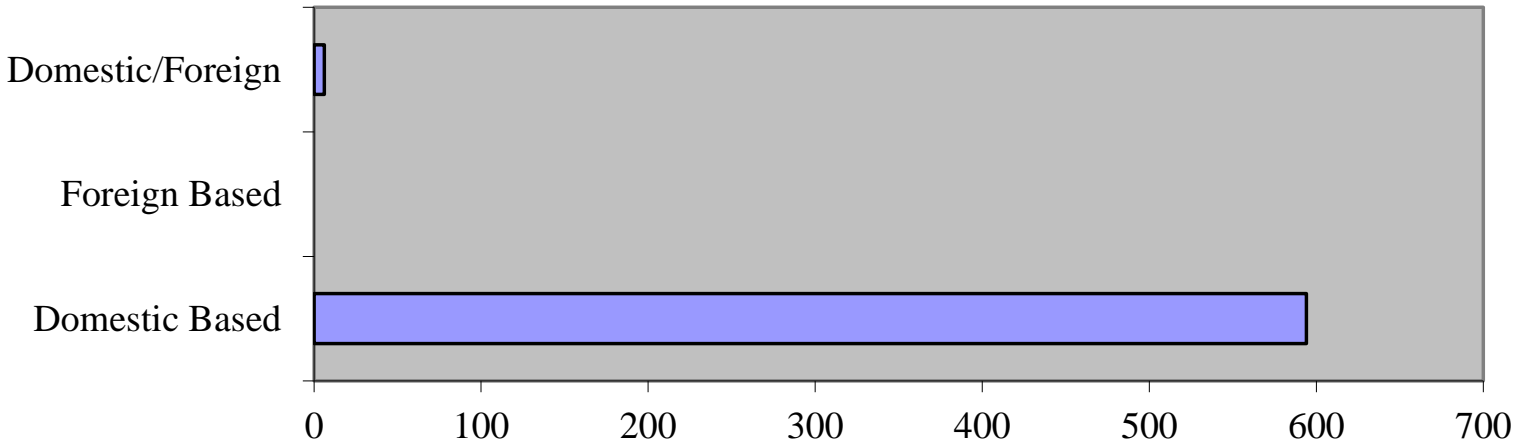

Figure 7: firm business operation category by frequency of respondents.

$\square$ business operation

The SME's involved in the research study as revealed by the table above are 99 percent domestic 
INTERNATIONAL JOURNAL OF ACADEMIC RESEARCH IN ACCOUNTING, FINANCE AND MANAGEMENT SCIENCES

Vol. 10 , No. 3, 2020, E-ISSN: 2225-8329 @ 2020 HRMARS

based business firm and 1 percent only that operates both domestically as well as foreign furthermore there is no firm sampled operating foreign based only.

Table 8: SME's sampled by form of ownership status

\begin{tabular}{|c|c|c|c|c|}
\hline Ownership & Frequency & Percentage & $\begin{array}{l}\text { Cumulative } \\
\text { frequency }\end{array}$ & $\begin{array}{l}\text { Cumulative } \\
\text { percentage }\end{array}$ \\
\hline $\begin{array}{l}\text { Sole } \\
\text { proprietorship }\end{array}$ & 318 & 53 & - & - \\
\hline Partnership & 54 & 9 & 372 & 62 \\
\hline $\begin{array}{l}\text { Private limited } \\
\text { liability }\end{array}$ & 174 & 29 & 546 & 91 \\
\hline $\begin{array}{l}\text { Cooperative } \\
\text { society }\end{array}$ & 30 & 5 & 576 & 96 \\
\hline Faith based & 18 & 3 & 594 & 99 \\
\hline Others & 6 & 1 & 600 & 100 \\
\hline
\end{tabular}

Source: Researcher's survey extracts 2020.

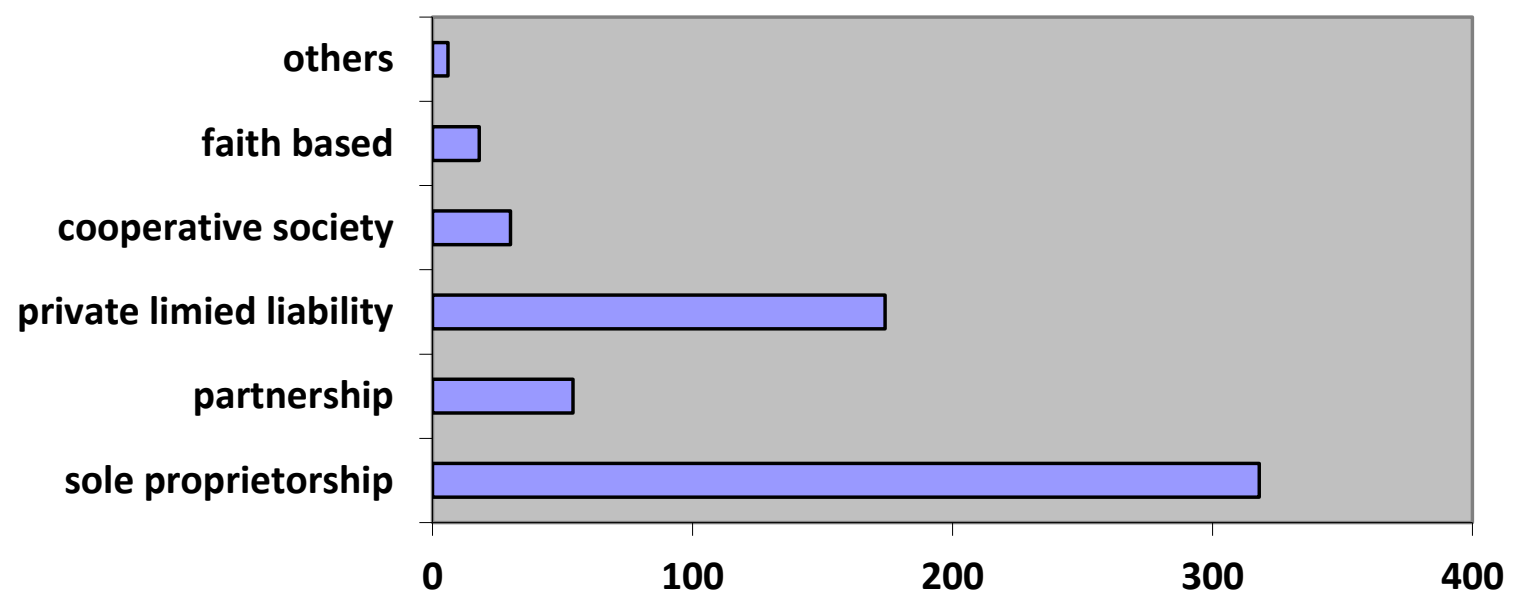

Figure 8: SME form of ownership by frequency of respondents.

\section{$\square$ Form of Ownership}

The form of ownership status of the sampled SME's majority are sole proprietorship enterprises followed by private limited liability and then by partnership business constituting 53 percent, 29 percent and 9 percent respectively. Other forms of ownership category are the least on the table having only 1 percentage point. 
INTERNATIONAL JOURNAL OF ACADEMIC RESEARCH IN ACCOUNTING, FINANCE AND MANAGEMENT SCIENCES

Vol. 10 , No. 3, 2020, E-ISSN: 2225-8329 @ 2020 HRMARS

Table 9: SME's distribution of goods produced by market location.

\begin{tabular}{|lcc|}
\hline Location & Frequency & Percentage \\
\hline Within locality & 470 & 78.33 \\
\hline & & \\
\hline Within town & 419 & 69.75 \\
\hline & & \\
\hline Within the state & 306 & \\
\hline & & 11.03 \\
\hline Inter states & 70 & \\
\hline & 39 & 6.50 \\
\hline ECOWAS & & \\
\hline
\end{tabular}

Source: Researcher's extracts from NBS/MAN various annual reports.

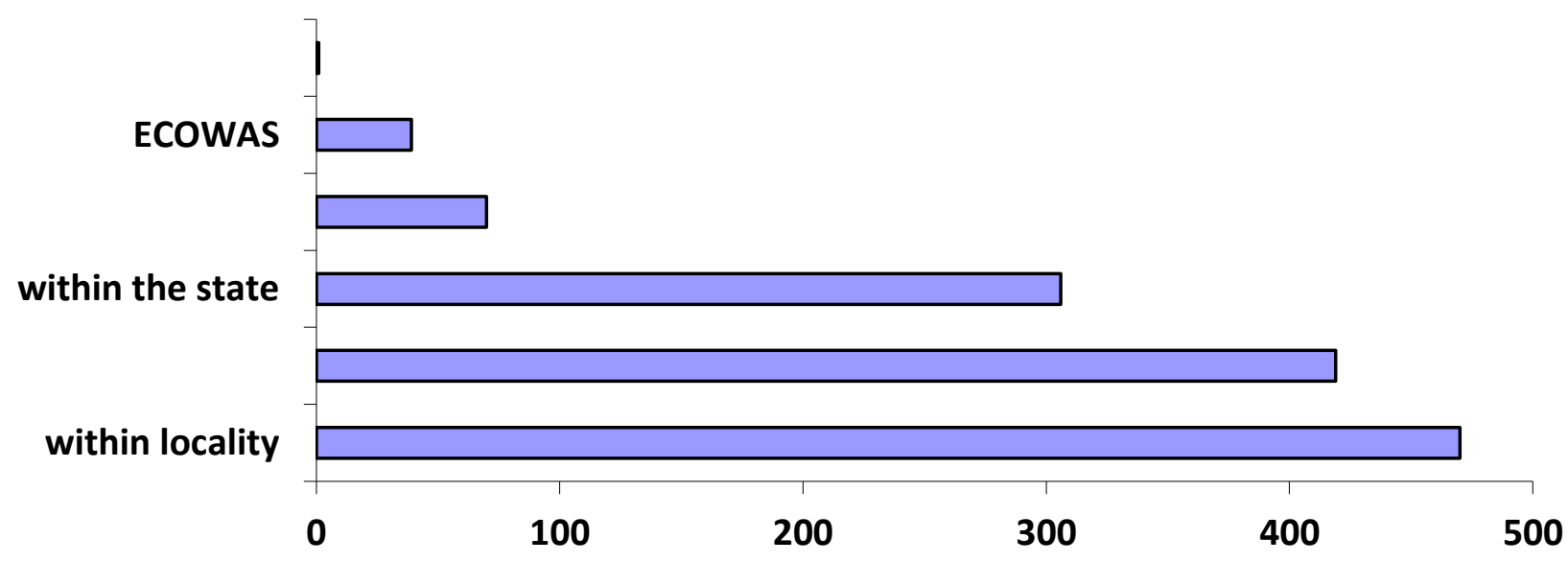

Figure 9: SME product distribution by market location.

\section{口Market Distribution}

The market location for the goods produced by the sampled SME's is dominated by within same locality having a percentage point of 78.33 followed by the distribution within the same town at 69.75 percent and within the same state at 51.03 percent. The product distribution markets with the least percentage is within Africa which has only 0.20 percent constituting only one firm. 
INTERNATIONAL JOURNAL OF ACADEMIC RESEARCH IN ACCOUNTING, FINANCE AND MANAGEMENT SCIENCES

Vol. 10 , No. 3, 2020, E-ISSN: 2225-8329 @ 2020 HRMARS

Table 10: SME's skills gap by form of ownership.

\begin{tabular}{lccccc} 
Ownership & $\begin{array}{l}\text { Qualified artisans } \\
\text { available }\end{array}$ & $\begin{array}{l}\text { Qualified artisans not } \\
\text { available }\end{array}$ & Total percent \\
\hline Srequency & (percent) & Frequency & (percent) \\
Sole proprietorship & 276 & $(46)$ & 324 & $(54)$ & 100 \\
Partnership & 228 & $(38)$ & 372 & $(62)$ & 100 \\
Private limited liability & 216 & $(36)$ & 384 & $(64)$ & 100 \\
Cooperative society & 246 & $(41)$ & 354 & $(59)$ & 100 \\
Faith based & 594 & $(99)$ & 6 & $(1)$ & 100 \\
\hline Others & 198 & $(33)$ & 402 & $(67)$ & 100
\end{tabular}

Source: Researcher's extracts from NBS/MAN various annual reports.

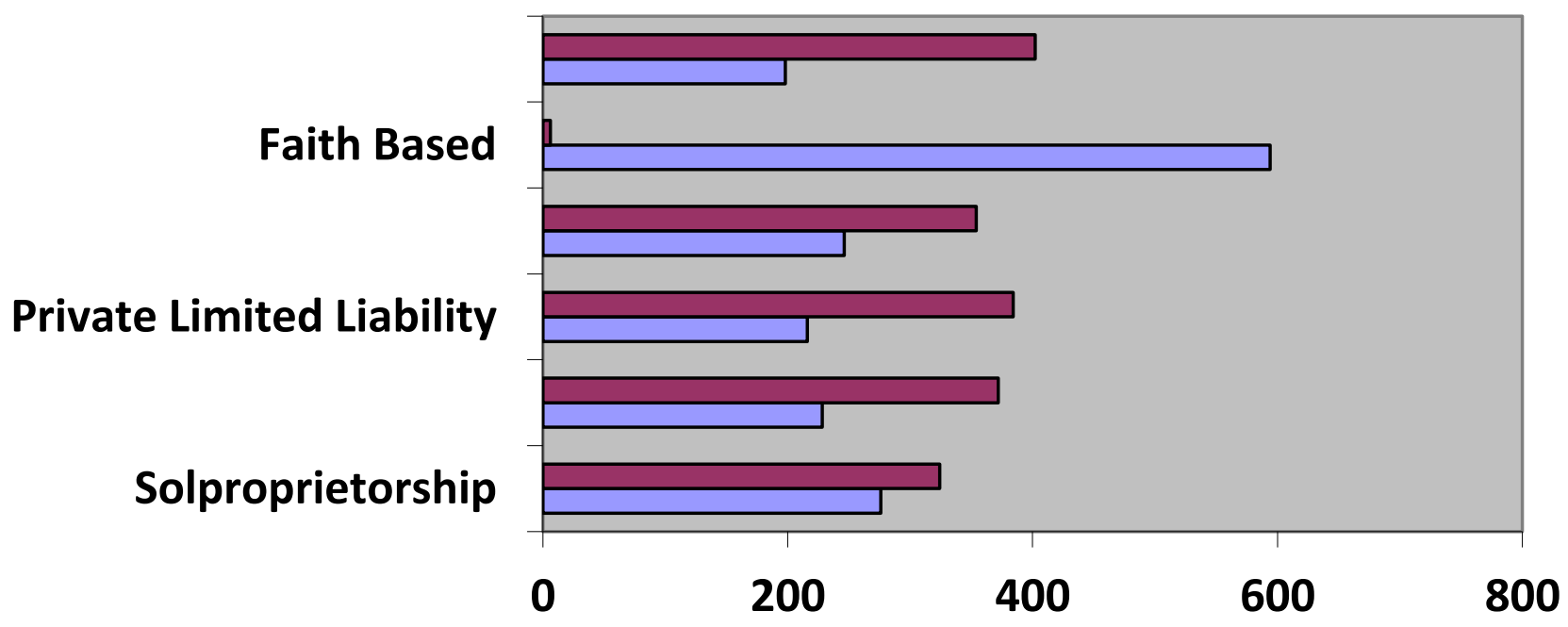

Figure 10: SME Skills gap by form of owner of the respondents.

\section{$\square$ Unavailable Artisans $\square$ Available Artisans}

The faith based SME's have the majority of skills utilization capacity revealing 99 percent of the qualified artisans are fully on ground followed by sole proprietorship with 46 percentage points and closely by cooperative societies with 41 percent. On the opposite site the other form ownership has the highest lag gap with 67 percent artisans not readily available followed by private limited liability at 64 percent and partnership at 62 percent. 
Table 11 SME's percentage of owned patent right by form of ownership

\begin{tabular}{l|ll}
\hline Ownership & Have Patent Right (\%) & No Patent Right (\%) \\
\hline Sole proprietorship & 4.37 & 95.63 \\
\hline Partnership & 20.74 & 79.26 \\
\hline Private Limited Liability & 1.23 & 98.77 \\
\hline Cooperative society & 0.00 & 100 \\
\hline Faith based & 0.73 & 99.27 \\
\hline Others & 7.13 & 92.87
\end{tabular}

Source: Researcher's extracts from NBS/MAN various annual reports.

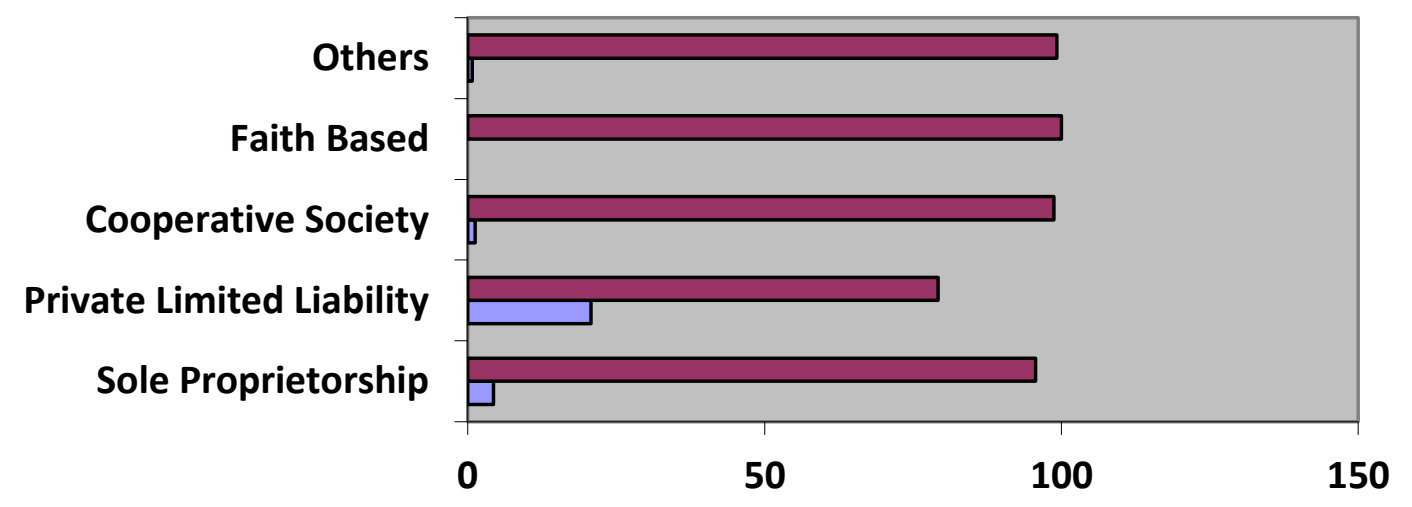

$\square$ Not Owned Patent Right $\quad \square$ Owned Patent Right

The form of SME's ownership that have the highest percentage points of owned patent right is the partnership with 20.74 percent secondly by others at 7.13 percent and thirdly by sole proprietorship 4.37 percent. It is also observed that the fraction of SME's that are duly registered patent right owners is very low compared to the fraction not registered for instance 99.27 percent, 98.77 percent and 95.63 percent is the fraction of unregistered patent right composition of faith based, private limited liability and sole proprietorship enterprises respectively.

Examining the impact of outsourcing accounting services on performance of SME's.

To make the analysis more significant some of the tables while presenting in the chart was split in to two i.e. the dominant economic subsectors such as the Food Beverages and Tobacco, Textile Footwear and Apparel and Other Manufacturing being separated from the rest of the economic subsectors. Therefore, from now henceforth some tables will be analyzed in two bar charts. 


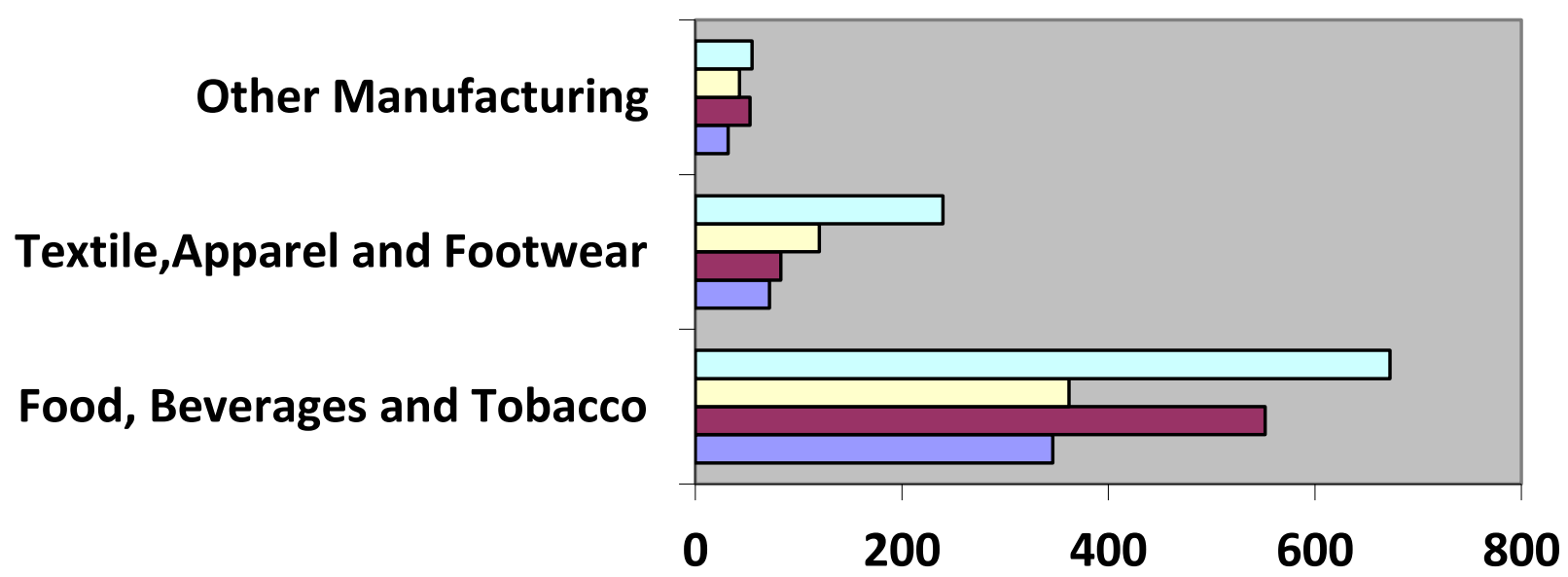

figure 12 : average monthly turnover in NGN millions of the dominant subsectors

\section{$2019 \square 2018 \square 2017 \square 2016$}

Food Beverages and tobacco has the highest turnover over the years under review, the turnover was NGN 346 million, NGN 552 million, NGN 362 million and NGN 672 million in 2016, 2017, 2018 and 2019 respectively. This has shown that there is a fluctuating trend in the turnover over the years but it has more increase. The total average turnover for the respective years for Food Beverages and Tobacco amounted to NGN 1.9 billion out of the grand total of NGN 2.9 billion for the whole economic subsectors. In this regard, the Food Beverages and Tobacco becomes the dominant factor amongst the subsectors constituting 65.52 percent of the total average turnover. The Textile, Apparel and Footwear accounted for average turnover of NGN 71.78 million, NGN 82.92 million, NGN 120.02 million and NGN 240.03 million 1n 2016, 2017, 2018 and 2019 respectively. It is the second dominant subsector and constitutes 17.49 percent of the total average for the four years' period. Other Manufacturing subsector is the third in generating average turnover with NGN31.77 million, NGN 53.14 million, NGN 42.62 million and NGN 55.14 million in 2016, 2017, 2018 and 2019 respectively which constitute six percent of the total turnover. From all indications the average turnover of the various subsectors has been steadily increasing with no fluctuation except for Food Beverages and Tobacco. 


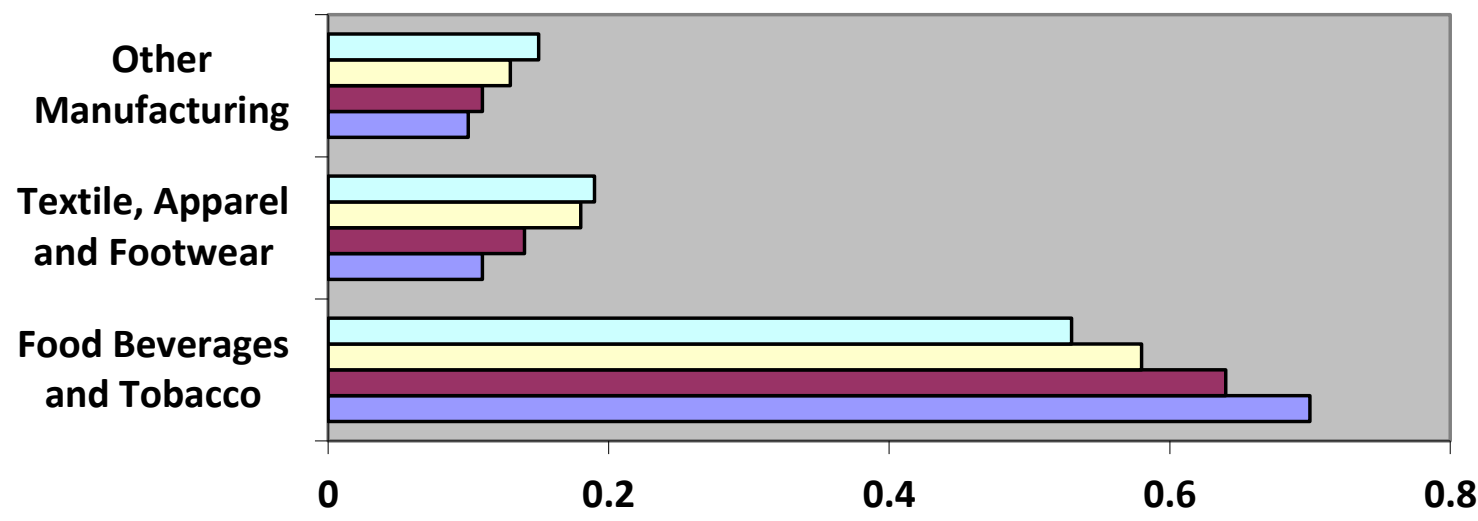

figure 13: profitability margin of the dominant subsectors

\section{$\square 2019 \square 2018 \square 2017 \quad \square 2016$}

The profitability margin of the subsectors was good still the Food Beverages and Tobacco subsector dominating with a wide range though losing some percentage points to the other competitors in the sector but yet dominant. The profitability margin of this dominant factor was at 70.38 percent in 2016 but tremendously decreased to 53.41 percent in 2019. This can be explained as a result of stiff competition by other sectors breaking the absolute advantage of the factor. Following then is the Textile, Apparel and Footwear with increasing profitability margin from 11.10 percent in 2016 to 18.54 percent in 2019. This therefore confirms that other sectors are striving hard to stay and compete favorably with other competitors notwithstanding their present status in the market. Other Manufacturing profitability margin also grew from 10.35 percent in 2016 to 14.94 percent in 2019. This is contrary to the decreasing margin in the Food Beverages and Tobacco subsector.

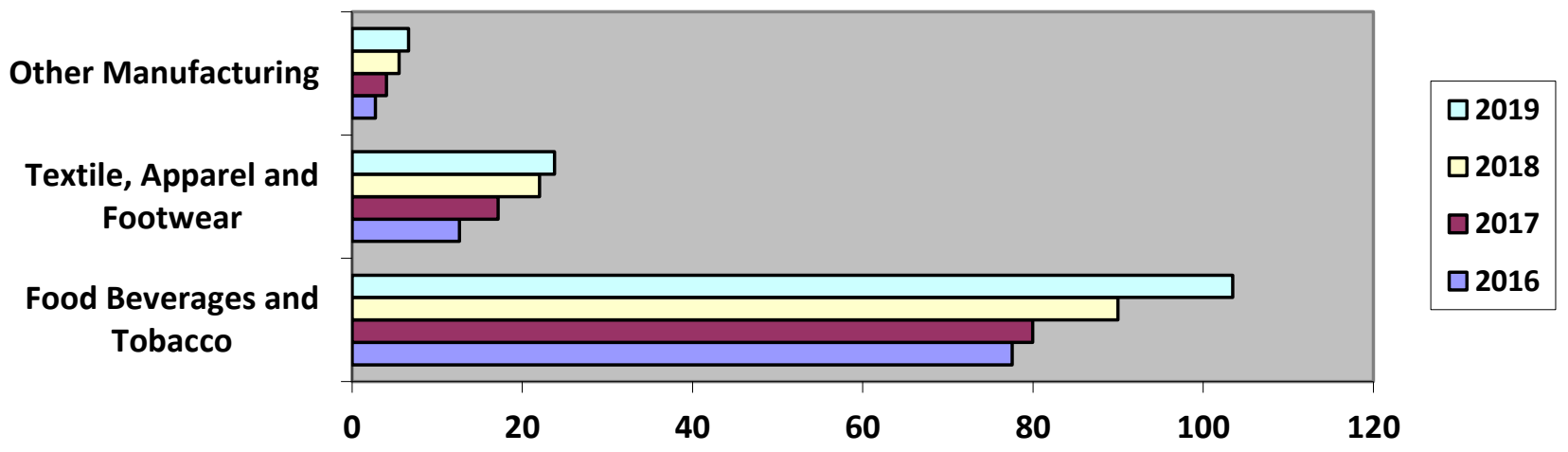

Figure 14 : Average monthly cost of operations in NGN millions of the dominant economic subsectors

The average monthly cost of operation increases year by year from both the dominant and the other subsectors. The higher average operational cost was incurred by Food Beverages and Tobacco in all the years under review as shown in figure 5.2.6, NGN 77.54 million, NGN 79.98 million, NGN 89.97 million and NGN 103.47 million in 2016, 2017, 2018 and 2019 respectively. As shown in figure 14. This reveals that the average monthly operational cost including staff emoluments increases with time. 
Furthermore, in figure 15 the subsectors second and third to Food Beverages and Tobacco in the chart are still Textile, Apparel and Footwear with NGN 12.62 million, NGN 17.17 million, NGN 22.01 million and NGN 23.79 million; Other Manufacturing with NGN 2.75 million, NGN 4.05 million, NGN 5.50 million and NGN 6.64 million in 2016, 2017, 2018 and 2019 respectively.

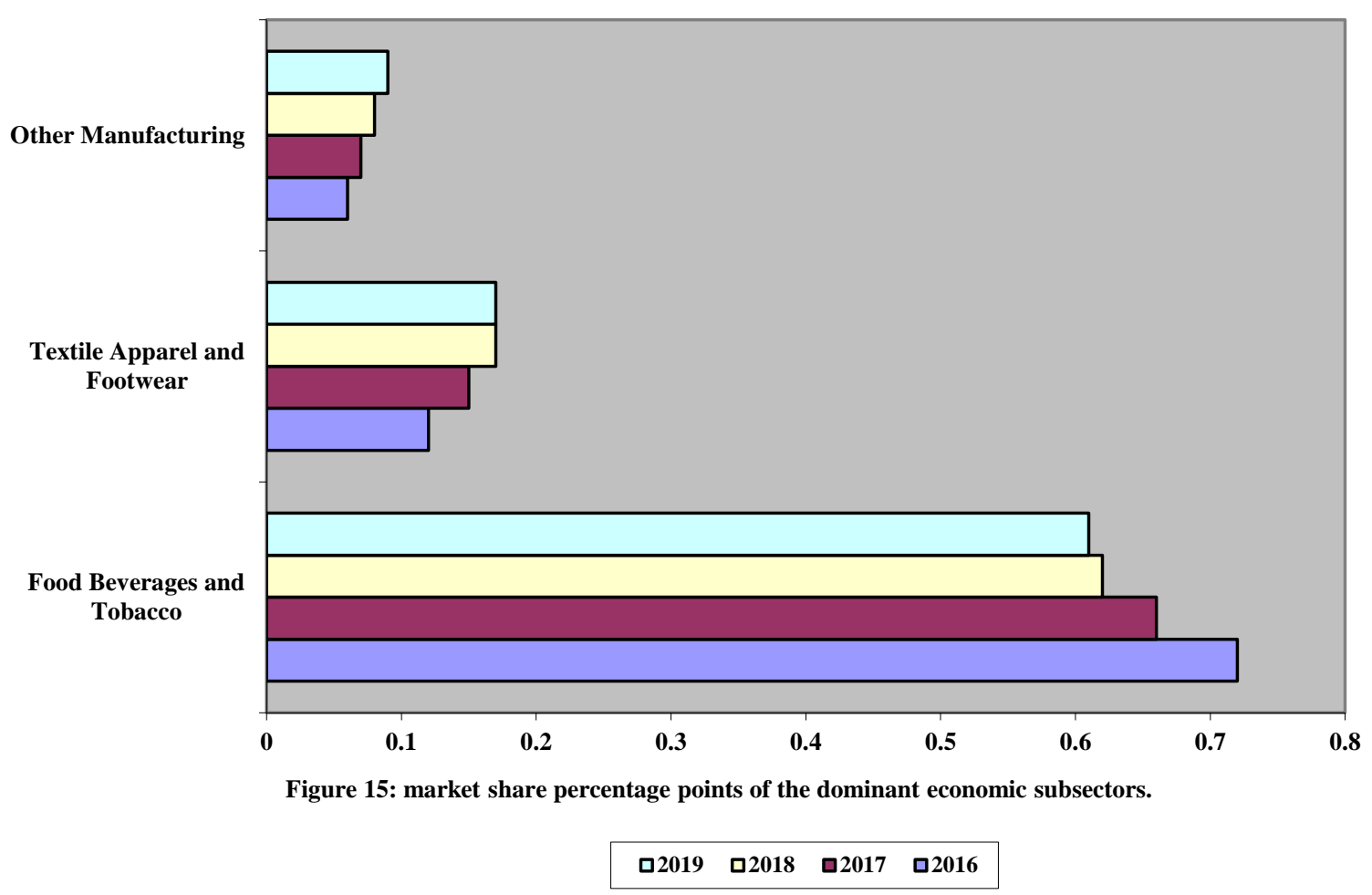

Figures 14 and 15 above explain the market share percentage of the SME's economic subsectors. Figure 14 reveals that 72 percent of the market share of the Nigerian SME's are Food Beverages and Tobacco in 2016, but the trends show a slight decrease over the years to 66 percent, 62 percent and 60 percent in 2017, 2018 and 2019 respectively. Food Beverages and Tobacco still maintained the lion market share thereby satisfying the needs of their customers better than any other economic subsector within the manufacturing cycle. This is followed by the Textile, Apparel and Footwear subsector with $11 \frac{1}{2}$ percent and by Other Manufacturing subsector occupying five percent of the market share. From this chart it's clearly viewed that the Food Beverages and Tobacco subsector despite the slight decrease in the market share over time but remains the market leader of all times during these years under review. 
INTERNATIONAL JOURNAL OF ACADEMIC RESEARCH IN ACCOUNTING, FINANCE AND MANAGEMENT SCIENCES

Vol. 10, No. 3, 2020, E-ISSN: 2225-8329 @ 2020 HRMARS

Table 12: Regression Result

\begin{tabular}{|l|l|l|l|l|l|l|}
\hline \multirow{2}{*}{ variables } & \multicolumn{3}{l}{ Other Manufacturing } & \multicolumn{2}{l}{$\begin{array}{l}\text { Food, Beverages \& } \\
\text { tobacco }\end{array}$} & \multicolumn{2}{l|}{$\begin{array}{l}\text { Textile, apparel \& } \\
\text { footwear }\end{array}$} \\
\cline { 2 - 7 } & Statistics & P-value & Statistics & P-value & Statistics & P-value \\
\hline constant & 16.979 & 0.0002 & 32.373 & 0.0000 & 21.353 & 0.0100 \\
\hline TRO & 7.343 & 0.0000 & 3.523 & 0.0300 & 1.323 & 0.0000 \\
\hline PRD & 3.456 & 0.0001 & 1.449 & 0.0012 & 3.457 & 0.0000 \\
\hline PRF & 5.373 & 0.0000 & 4.373 & 0.0013 & 2.973 & 0.0045 \\
\hline OPR & -6.975 & 0.0005 & -2.373 & 0.0000 & -1.353 & 0.0210 \\
\hline IND & -2.135 & 0.0000 & -3.009 & 0.0022 & 4.579 & 0.0113 \\
\hline CSS & 5.677 & 0.0020 & 1.777 & 0.0021 & -2.337 & 0.0333 \\
\hline$R^{2}$ & 0.789 & & 0.887 & & 0.733 & \\
\hline Adj. $R^{2}$ & 0.697 & & 0.819 & & 0.651 & \\
\hline F-Value & 20.223 & & 4.767 & & 12.338 & \\
\hline
\end{tabular}

Note: predictor variables, $\mathrm{TRO}=$ turnover, $\mathrm{PRD}=$ productivity, $\mathrm{PRF}=$ profitability, OPR=operating cost, IND=independence and CSS=customer satisfaction

The result revealed that all the predictor variables are having positive relationship with the constant variable as predicted by the study. Food, Beverages and Tobacco (FBT) has the highest $\mathrm{R}^{2} 81.9 \%$ followed by Other Manufacturing (OTM) 69.7\% and Textile, Apparel and Footwear (TAF) 65.1\%. The relationship between turnover and accounting services outsourcing propensity produced a coefficient value of $\beta=7.343 ; 32.373$ and 21.353 ( $S E=0.044 ; C . R=-2.465, p=0.0002 ; 0.0000 \& 0.0100$ ). The probability of getting a critical ratio as large as 2.545 in absolute value is 0.0051 on average. In other words, the regression weight for sales in naira value in the prediction of outsourcing propensity to efficiency and financial performance is significantly not different from zero at the 0.05 level (twotailed). Therefore, positive coefficient for sales value indicates support for which specified that turnover is positively linked to accounting services outsourcing propensity to enhance efficiency and financial performance of SMEs in Nigeria.

The coefficient value for the route from trust to accounting services outsourcing propen sity as shown table 12 above, ( $S E=0.035 ; C . R=4.760)$. The probability of getting a critical ratio as large as 4.760 in absolute value is less than 0.001 . In other words, the regression weight for productivity, profitability and customer satisfaction in the prediction of outsourcing intensity is significantly not different from zero at the 0.001 level (two tailed). Consequently, a significant positive coefficient for these three variables signified that both variables are significantly positively related with the each other hence, direct relationship of the predictor variables with financial performance of the sampled SMEs in Nigeria.

The coefficient value for the path from accounting services outsourcing propensity to SME independence and operation cost is $\beta=0.744$ ( $S E=0.022 ; C . R=33.179)$. The probability of getting a critical ratio as small as 0.179 in absolute value is less than 0.001 . In other words, the regression weight for outsourcing propensity in the prediction of SME operational cost and patent/copy right registration is significantly different from zero at the 0.001 level (two-tailed). Hence, this is indicating a significant negative link between SME independence, operation cost, efficiency and financial 
performance.

\section{Conclusion and Recommendation}

This study was focused on the impact of accounting functions outsourcing on the efficiency and financial performance of some selected SMEs in Nigeria. The study found significant positive relationship between the dependent variable and four predictor variables turnover, profitability, productivity and customer satisfaction whereas, two predictor variables patent/ copy right and independence emerge to be negatively but significant relationship with the dependent variable as predicted. In line with these findings accounting functions outsourcing was considered significant in intensification of speed of work as well as strengthened organizational efficiencies.

Hence, the study recommended that accounting functions be outsourced by SMEs to fortify financial performance and enterprise efficiency. Furthermore, this study suggests that further researchers should attempt to gather data from different sectors other than manufacturing and without paying special attention to the size of organizations. Hence, appraisal amid Micro, Small, Medium and large Enterprises engaged in accounting functions outsourcing attained. This pool of enterprises if studied together will reveal the relevant distinctions in accounting functions outsourcing and interrelations amongst all sizes of firms. Hence, will tackle the issues related to the generalizability of findings as it is found to be a limitation to this current study.

\section{Reference}

Baiye, C. (2012). Outsourcing: Seeking growth through the Indian model. The Punch Retrieved on $3^{\text {rd }}$ July, 2020 from <www.punchng.com/opinion/outsourcing-seekinggrowth-through-the Indian-model.

Bulter, J. T. (1991). Elements of Administration for Building students, 2nd Edition, Hutchinson press Ltd, London.

Coase, R. H. (1937). The nature of the firm. Economica. 4(16): 386-405.

Corbett, M. F. (2004). Outsourcing Revolution: Why it Make Sense and How to Do it Right. Chicago IL. USA Dearborn Trade. A Kaplan Professional Company.

Dana, (2012). Types of outsourcing. Retrieved on 8th August 2020 from $<$ http://www.typesofoutsourcing.net/?p=B

Densai, R. (2012). Meaning of Outsourcing. Retrieved on 5th October 2020 from

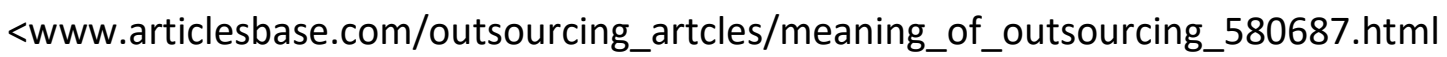

Everaert, P., Sarens G. and Rommel, J. (2010). Using transaction cost economics to explain outsourcing of accounting. Small Business Economics, 35(1): 93-112.

Gandja, S. V., and Estay, C. (2012). Make-or-Buy Decisions: What Choice for an Accounting Services in a Developing Country? International Journal of Academic Research in Accounting, Finance and Management Sciences, 2(4): 260-272.

Hafeez, A., Andersen, O. (2014). Factors Influencing Accounting Outsourcing Practices among SMEs in Pakistan context: Transaction Cost Economics (TCE) and Reource Based View (RBV) Prospective. International Journal of Business Management, 9(7): 19-32.

Hamel, G., and Prahalad, C. K. (1994). Competing for the Future. Boston: Harvard Business School Press.

Kamyabi, Y., and Devi, S. (2011). An empirical investigation of accounting outsourcing in Iranian SMEs: 
Transaction cost economics and resource-based views. International Journal of Business and Management, 6(3): 81-94.

Mohammed, D. (2014). Outsourcing accounting functions as means of enhancing records keeping: Evidence from SMEs in Adamawa State, Nigeria. Proceedings of the annual researchsymposium. Faculty of Graduate Studies University of Colombo Sri Lanka 43-46.

NBS/SMEDAN (2010). Survey Report on Micro, Small and Medium Enterprises (MSMEs) in Nigeria. 2010 National MSMEs Collaborative survey Between National Bureau of Statistics and Small and Medium Enterprises Development Agency of Nigeria.

Prahalad, C. K., \& Hamel, G. (1990). The core competence of the corporation. Harvard Business Review, 68(3), 79-93.

Small and Medium Scale Enterprises Development Agency of Nigeria (SMEDAN) Act. [2003 No. 16.2004 No. 12.]

Smedan. (2015). National Policy on Micro, Small and Medium Enterprises (MSMEs) in Nigeria. A Policy Document Prepared by Small and Medium Enterprises Development Agency of Nigeria and Approved by the Federal Executive Council.

Suraju, R. F., and Hamed, A. B. (2013).Outsourcing Services as a Strategic Tool for Organisational Performance: An Explanatory Study of Nigerian Food Beverages and Tobacco Industry. Journal of Management Policies and Practice, 1(1): 01-20.

Williamson, O. E. (1975). Markets and Hierarchies: Analysis and Antitrust Implications. A Study in the Economics of Organization. New York: The Free Press. 